\title{
Transcription Activator BRG1
}

National Cancer Institute

\section{Source}

National Cancer Institute. Transcription Activator BRG1. NCI Thesaurus. Code C19845.

Transcription activator BRG1 (1647 aa, $\sim 185 \mathrm{kDa}$ ) is encoded by the human SMARCA4 gene. This protein plays a role in the mediation of both chromatin remodeling and transcription. 